\title{
Mechanistic Targets and Nutritionally Relevant Intervention Strategies to Break Obesity-Breast Cancer Links
}

\author{
Ximena M. Bustamante-Marin ${ }^{1}$, Jenna L. Merlino ${ }^{1}$, Emily Devericks ${ }^{1}$, \\ Meredith S. Carson ${ }^{1}$, Stephen D. Hursting ${ }^{1,2}$ and Delisha A. Stewart ${ }^{1,2 *}$ \\ ${ }^{1}$ Department of Nutrition, University of North Carolina, Chapel Hill, NC, United States, ${ }^{2}$ Nutrition Research Institute, \\ University of North Carolina, Kannapolis, NC, United States
}

OPEN ACCESS

Edited by:

Riccarda Granata,

University of Turin, Italy

Reviewed by:

Alfeu Zanotto-Filho,

Federal University of Santa Catarina,

Brazil

Vittoria D'Esposito,

Consiglio Nazionale Delle Ricerche

(CNR), Italy

Teresa Gagliano,

University of Udine, Italy

*Correspondence:

Delisha A. Stewart

delisha_stewart@unc.edu

Specialty section:

This article was submitted to

Obesity,

a section of the journa

Frontiers in Endocrinology

Received: 15 January 2021 Accepted: 17 February 2021

Published: 17 March 2021

Citation:

Bustamante-Marin XM, Merlino JL, Devericks E, Carson MS, Hursting SD and Stewart DA (2021) Mechanistic

Targets and Nutritionally Relevant Intervention Strategies to Break

Obesity-Breast Cancer Links.

Front. Endocrinol. 12:632284.

doi: 10.3389/fendo.2021.632284
The worldwide prevalence of overweight and obesity has tripled since 1975. In the United States, the percentage of adults who are obese exceeds $42.5 \%$. Individuals with obesity often display multiple metabolic perturbations, such as insulin resistance and persistent inflammation, which can suppress the immune system. These alterations in homeostatic mechanisms underlie the clinical parameters of metabolic syndrome, an established risk factor for many cancers, including breast cancer. Within the growth-promoting, proinflammatory milieu of the obese state, crosstalk between adipocytes, immune cells and breast epithelial cells occurs via obesity-associated hormones, angiogenic factors, cytokines, and other mediators that can enhance breast cancer risk and/or progression. This review synthesizes evidence on the biological mechanisms underlying obesity-breast cancer links, with emphasis on emerging mechanism-based interventions in the context of nutrition, using modifiable elements of diet alone or paired with physical activity, to reduce the burden of obesity on breast cancer.

Keywords: obesity, breast cancer, inflammation, metabolism, immunosuppression, hormone signaling, nutrition

\section{INTRODUCTION}

Obesity is a state of increased adiposity defined by a body mass index (BMI) $\geq 30 \mathrm{~kg} / \mathrm{m}^{2}$ (1). Current global estimates suggest that 1.97 billion adults are overweight $\left(B M I=25.0-29.9 \mathrm{~kg} / \mathrm{m}^{2}\right)$ and over 650 million are obese (2). By 2030, it is estimated $57.8 \%$ of the global adult population will be overweight or obese if current trends continue $(3,4)$. The impacts of obesity on human physiology include dysregulation of insulin, bioavailable insulin-like growth factor (IGF)-1, adipokines (e. g. leptin and adiponectin), inflammatory factors (e. g. cytokines), and vascular integrity-related factors (e. g. vascular endothelial growth factor (VEGF)) $(3,4)$. As a result, multiple diseases are associated with obesity, including hypertension, dyslipidemia, type 2 diabetes, coronary heart disease, and several cancers (5).

Breast cancer (BC) is the most common cancer in women worldwide (6). As a heterogeneous disease, $\mathrm{BC}$ subtypes have been extensively described elsewhere (7). Briefly, the intrinsic subtypes are classified by hormone receptor positive/human epidermal growth factor receptor 2 negative $\left(\mathrm{HR}^{+} /\right.$ HER2 2 , Luminal A), $\mathrm{HR}^{+} / \mathrm{HER} 2^{+}$(Luminal B), HR $/ \mathrm{HER}^{+}$(HER2-enriched), $\mathrm{HR}^{-} / \mathrm{HER}^{-}$(basal-like or triple negative breast cancer, TNBC), and claudin-low (TNBC-metaplastic) $(8,9)$. Worldwide, there 
were over 2 million new BC cases in 2018 (6); and global epidemiological patterns show the importance of cultural and lifestyle factors, with only 5-10\% of BCs being inherited (10). An estimated $\sim 20-50 \%$ of BC can be attributed to modifiable risk factors, including physical inactivity and nutritional choices that result in obesity (11).

Obesity-driven BC risk is associated with multiple factors including menopausal status (12). Further, the risk of developing postmenopausal BC is exacerbated by obesity (13). These women have worse disease-free and overall survival despite appropriate therapeutic approaches. Results from a meta-analysis of 34 cohort studies with over 2.5 million women found that with each $5 \mathrm{~kg} / \mathrm{mg}^{2}$ increase in BMI, there is a $12 \%$ increase in risk of postmenopausal BC (14). The risk is further dependent on other factors including, BC subtype $(15,16)$, race/ethnicity (16-18), estrogen and progestin use (18) and hormone receptor status (19). Obese BC patients also experience complications during surgery, radiation, and chemotherapy, and are at increased risk for local recurrence. Additionally, there is a greater probability for increased tumor size, metastatic rates, resistance to endocrine therapy, and advanced disease stage at diagnosis $(19,20)$. While obesity is known to increase postmenopausal, $\mathrm{HR}^{+} \mathrm{BC}$ risk (13), more recent studies assessing central adiposity revealed that high abdominal obesity increases risk for ER- and TNBC in premenopausal women $(13,16,21,22)$. Similarly, in preclinical animal model studies, mammary tumor development and progression of $\mathrm{HR}^{+}$, basal-like and claudin-low subtypes is exacerbated by obesogenic environments $(1,23)$. In contrast, only minimal clinical and pre-clinical data supports that the Luminal B and HER2 subtypes, are enhanced by obesity $(1,24)$.

Here we focus on nutritional and physical activity-based interventions shown to ameliorate obesity-associated enhancements of growth signaling, inflammation, angiogenesis, and metastatic processes in BC. We also discuss gaps and potential uses of these strategies to mitigate obesity pro-BC effects.

\section{THE ROLE OF GROWTH FACTOR AND HORMONE SIGNALING IN OBESITY- BREAST CANCER LINKS}

Overweight and obese patients have increased risk of developing hormone and growth factor perturbations resulting in insulin resistance, increased production of estrogen, enhanced insulinlike growth factor (IGF)-1 bioavailability and a decreased adiponectin/leptin ratio. These can all increase BC incidence, tumor development, progression, and worsen clinical outcomes.

\section{Insulin and Insulin-Like Growth Factor-1}

Most obese patients have high levels of insulin, increased bioavailable IGF-1, low levels of IGF binding proteins (IGFBPs), and higher steady state levels of mTOR activation $(25,26)$ (Figure 1). Insulin, produced by pancreatic beta cells and released in response to elevated blood glucose, predominantly mediates metabolic activity whereas IGF-1, primarily produced by the liver, controls long-term action to determine cellular fates. IGF-1 bioavailability is regulated by IGF binding proteins (IGFBPs) 1-6, which regulate IGF-1 binding to the IGF-1 receptor (IGF-1R) and cross-reactivity with the insulin receptor (IR) (27). The activation of IR and IGF-1R lead to downstream phosphorylation cascades that promote the PI3K/AKT/mTOR and RAS/RAF/mitogen activated protein kinase (MAPK) pathways. These signaling pathways are associated with cancer development and progression $(1,28,29)$. The connection between insulin and BC risk has been shown in several meta-analyses $(30,31)$, suggesting that hyperinsulinemia and elevated basal insulin levels increase BC risk and are a negative predictor of BC prognosis (31-33).

\section{Estrogen and Aromatase}

The production of estrogen in the adipose tissue of obese patients, secondary to increased aromatase activity, has been found to be a key driver of $\mathrm{BC}(21,34)$. The rapid expansion of adipose tissue observed during weight gain in obese women causes a rise in pre-adipocytes expressing aromatase (35). The tumor microenvironment, rich with adipocytes, is also a source of estrogen production and aromatase expression in BC cases, and can contribute up to 10 -fold increased levels of estrogen in breast tumors compared to levels in surrounding tissue (3). In $\mathrm{ER}^{+} \mathrm{BC}$, increased $\mathrm{ER} \alpha$ promotes cell proliferation (36), and obesity is positively associated with $\mathrm{ER} \alpha$ positive tumors (37).

\section{Leptin, Adiponectin, and Their Ratio}

In the obese state, the dysfunctional adipose tissue overproduces the hormone leptin, causing leptin resistance $(38,39)$ and reducing the adiponectin/leptin ratio (40) (Figure 1), which is negatively associated with BMI $(41,42)$. High levels of leptin through its receptor, Lepr, activate the Janus kinase and signal transducer activator of transcription (JAK/STAT) pathway that is often dysregulated in cancer (43). Hyperleptinemia also stimulates mitogenesis, angiogenesis, and the secretion of proinflammatory cytokines such as interleukin (IL)-6, tumor necrosis factor (TNF)- $\alpha$, IL-2 and interferon (IFN)- $\gamma$ (44). High leptin levels and reduced adiponectin/leptin ratio were associated with an increased risk of postmenopausal BC in a multiethnic case-control study $(45,46)$. Similar results have been documented in preclinical models of BC (47).

\section{Interventions to Break Growth Factor and Hormone-Signaling-Associated Obesity- Breast Cancer Links}

Many nutritional and lifestyle habits can modify BC risk. Physical activity, for example, has many benefits including promotion of weight loss, reduction of hormone levels $(48,49)$, regulation of insulin and IGF-1 bioavailability, and normalization of leptin/ adiponectin ratio $(50,51)$. According to the National Cancer Institute, exercising for four or more hours per week decreases BC risk (52). This is supported by epidemiological studies that observed inverse relationships between physical activity and risks of $\mathrm{BC}(53,54)$. Interventions designed to reduce calorie intake, such as, calorie-restricted diets and intermittent fasting, can reverse the high levels of insulin and IGF-1 (55-57) (Figure 1). However, there is no consensus regarding the impact of diet 


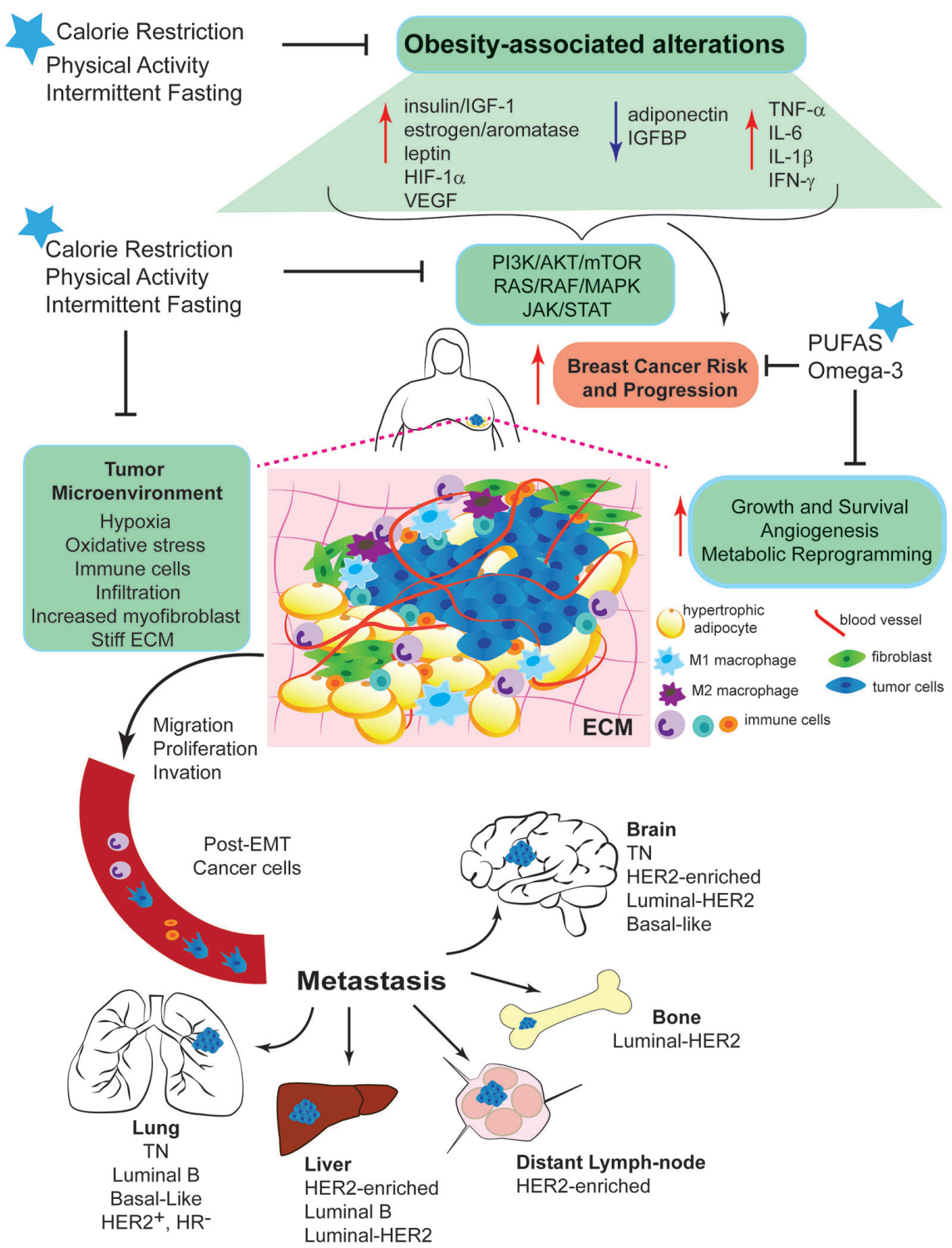

FIGURE 1 | Mechanisms linking obesity with breast cancer development and intervention strategies to break Obesity-Breast Cancer Links. Increased energy intake and low physical activity results in obesity. Excess adiposity causes systemic changes, such as increased circulating levels of insulin/IGF-1, aromatase activity, estrogen production, and leptin:adiponectin ratio. Local changes due to the hyperplasia and hypertrophy of adipocytes, leads to a pro-inflammatory response promoting the secretion of cytokines and inflammatory molecules. These systemic and local changes activate key signaling pathways (PI3K/AKT/mTOR, RAS/RAF/ MAPK, and JAK/STAT). The complex interplay among all of these alterations generates a microenvironment favorable for breast epithelial cell transformation and increase breast cancer risk and progression. Dysfunctional adipocytes, distant and present within the tumor microenvironment, produce high levels of leptin that contributes to chronic inflammation and BC progression. Obesity promotes cell proliferation, migration and invasion, epithelial-mesenchymal transition (EMT), angiogenesis and recruitment of immune cells. Obesity increases myofibroblast content, which stiffens the extracellular matrix (ECM) and enhances cancer cell growth. All these effects stimulate the entry of invasive cells into the circulation and the subsequent metastatic colonization of distant organs, such as bone, lung, liver and brain. Nutritional interventions, such as calorie restricted diets with balanced protein content and intermittent fasting can break the obesity-BC links, the benefits of the dietary interventions can be further improved by increasing daily physical activity.

and exercise on IGF-1 and IGFPB. Although there are limited clinical studies in the field, a recent study in young obese females showed that 4-weeks of aerobic exercise (6 days/week, two hours twice a day) combined with a diet intervention (daily energy intake of 1,400 or 1,600 calories) reduced the serum levels of IGFBP-3 while increasing the activity of IGF-1; however the intervention did not affect the total serum levels of IGF-1 (58). A different study showed that 5 weeks of diet combined with 45 minutes of moderated-to-intensive exercise has no impact on IGF-1 and IGFBP levels in overweight or obese women, but the molar ratio IGF-1/IGFBP3 was significantly increased by the intervention (59). Better reduction of total IGF-1 serum levels 
might be achieved with longer intervention times. Low circulating levels of IGF-1 were reached after 16 weeks of strength training (60). High levels of IGF-1 could be lowered temporarily by bariatric surgery (55); however, for long term reduction of IGF1 level, a nutritional intervention is necessary to maximize the effects of the surgery on IGF-1 levels $(55,61)$. Dietary interventions (55-57), in particular, a 2008 study by Fontana et al. demonstrated total caloric restriction (CR) and targeted protein reduction was needed to lower circulating serum IGF-1, albeit in a small study of six participants (56); however a recent meta-analysis of six clinical trials corroborated these findings in part, showing an increase in circulating IGF-1 in response to increased protein intake (57). Studies in mice have also shown that low circulating IGF-1 correlates with reduced mammary tumor volume $(1,62)$. Thus, further investigation is warranted on the role of $\mathrm{CR}$ and macronutrient ratio modification methods to determine whether the $\mathrm{BC}$ associated to obesity with IGF dysfunction can be disrupted by these strategies.

Regarding dietary components, BC researchers have long investigated the impact of nutritional strategies to decrease the risk of $\mathrm{BC}$ and improve treatment outcomes. For example, plantbased diet interventions, rich in fiber, antioxidants, and phytochemicals could reduce $\mathrm{BC}$ incidence. In recent years intermittent fasting has emerged as a strategy to reduce adipose tissue and improve insulin levels, which can also lower estrogen levels and slow the growth of breast tumors. It was shown that short-term fasting 24 hours before and after chemotherapy can reduce the cytotoxicity of neoadjuvant docetaxel/doxorubicin/ cyclophosphamide treatment in HER2 ${ }^{-}$BC $(63,64)$. Intermittent fasting impacts multiple cancer related pathways (Figure 1), including reducing IGF-1 and increasing IGF1BP by negatively regulating growth hormone-mediated IGF-1 mRNA production $(65,66)$. Fasting lowers blood glucose and circulating insulin levels, this could result in suppression of PI3K/Akt and reduction of mTOR activity. Studies using mouse models have shown that mTOR inhibitors block the tumor-enhancing effects of obesity (67), indicating that mTOR inhibitors in combination with intermittent fasting could represent a potential strategy for breaking the obesity-BC link. Nutritional-dependent mitigation strategies to facilitate mTOR repression, could include the incorporation of cardamonin found in cardamom spice and other plants and flavonoids in the diet $(68,69)$.

\section{MEDIATORS OF INFLAMMATION AND IMMUNOSUPPRESSION IN OBESITY- BREAST CANCER LINKS}

Chronic inflammation is an established hallmark of cancer (7072), and represents a highly relevant mechanistic target for nutrition and cancer research (Figure 1). Stromal breast tissue communicates with tumor cells in the microenvironment to usurp homeostatic inflammatory and resolution mechanisms, increase genomic instability, and recruit immune cells, further propagating inflammatory signals and increasing cancer cell survival. Failure to resolve inflammation often occurs with obesity, and the mechanisms underlying this are under intense investigation (73). Well described inflammatory mediators include transcription factors (i.e., NF- $\mathrm{\kappa B}$ ), soluble signaling molecules (i.e., cytokines, chemokines, growth factors, and specialized pro-resolving mediators) and their receptors, and immune cell populations (e.g., tumor-associated macrophages and T-cells) (74-78).

\section{Cytokines and Pro-Inflammatory Mechanisms}

Cytokines are small proteins that coordinate immune responses to assist with re-establishing homeostasis following insult or injury (79). Many cytokines have pleiotropic activity making interpretation of their expression patterns and downstream consequences difficult in the disease context $(80,81)$. However, several are useful biomarkers of systemic dysfunction when unchecked inflammation does not resolve, including angiogenin, IL-1 $\beta$, IL-6, IL-17, osteopontin, osteoprotegerin, RANTES, TNF- $\alpha$ and TGF- $\beta$, linking persistent inflammatory mechanisms to arthritis, type 2 diabetes, obesity and cancer (82$85)$. NF- $\mathrm{\kappa B}$ is a master regulator coordinating genetic, metabolic and inflammatory instabilities in many cancers, primarily by increasing cytokine levels and signaling, and these effects are typically more dysregulated in obese patients (86). Proinflammatory signaling can promote BC proliferation, angiogenesis, invasion, metastasis repress tumoricidal host immunosurveillance programs and decrease chemotherapeutic treatment response (87-91) (Figure 1).

Under obesogenic conditions, the crosstalk between dysregulated adipose tissue, inflammatory mediators and tumor cells can have adverse impacts on BC outcomes (92). Autocrine and paracrine signaling mechanisms drive anti- and pro-inflammatory signals within the tumor microenvironment, linking inflammation to tumor aggressiveness, disease progression and chemoresistance programs $(92,93)$. This communication, which also includes other stromal components (i.e., fibroblasts and tumor-adjacent normal tissue), creates a milieu promoting genetic instability that enhances every aspect of BC progression from increasing proliferation, reducing apoptosis, and facilitating angiogenesis, migration, and ultimately metastasis (94). In obese women, systemic abnormalities can also include comorbidities like nonalcoholic fatty liver disease, shown to interfere with expression of several cytochrome P450 genes involved in drug metabolism, contributing to obesity-associated reductions chemotherapeutic efficacy $(95,96)$.

\section{Obesity, Breast Cancer, and Immunosuppression}

Breast tumors are usually infiltrated by multiple immune cell populations, most notably macrophages, referred to as tumorassociated macrophages (TAMs), as well as neutrophils and T-cells, that can reduce treatment efficacy through immunosuppressive mechanisms $(76,97)$. Grimm and colleagues reviewed how persistent pro-inflammatory cytokine and chemokine signaling (including IL-4, IL10, IL-13 and TGF- $\beta$ ) increases reactive oxygen and nitrogen species, enhancing programs related to oxidative stress and nitrosylation, which initially recruits tumoricidal macrophages (M1 phenotype) that switch to a pro- 
tumor (M2/TAMs) phenotype. This microenvironmental mechanism of immunosuppression interferes with proper recruitment of regulatory $\mathrm{T}$-cells, through arginase upregulation (98). Karki and Kanneganti describe a similar dichotomous role of inflammasomes driving immunosuppressive programs by inhibiting the antitumor activity of $\mathrm{T}_{\text {helper }}$ cells (CD4+, CD8+), also involving myeloid-derived suppressor cells, natural killer cells and TAMs (89). Thus, increased levels of circulating inflammatory cytokines and recruitment of certain immune cell populations can propagate tumor phenotypes, resulting in poorer outcomes. Targeting specific cell populations or blocking the soluble factors that drive them is emerging as a promising approach for disrupting obesity-influenced cancer links (92, 93, 99).

\section{Nutritional Strategies That Mitigate Breast Cancer-Promoting Immune Mechanisms}

Obesity is one of the most prevalent conditions by which low-grade inflammation becomes a chronic and systemic problem. Modulation of several specific dietary components represents a viable intervention strategy to offset the immunosuppressive and procancer effects of obesity (100). For example, many in vivo studies have demonstrated the capability of long chain $n-3$ polyunsaturated fatty acids (PUFAs) to reduce adipose-associated leptin and cytokine levels (i.e., TNF $\alpha$, IL-6 and MCP-1), and increase anti-inflammatory adiponectin (101-104) (Figure 1). By reducing obesity-associated inflammation, PUFAs like eicosanoids exert chemoprotective effects, including, decreased proliferation and increased apoptosis, shown to reduce BC tumor burden and metastasis $(105,106)$. Kanaya and colleagues demonstrated the benefit of whole blueberry extract to modulate cytokine signalling and inhibit TNBC metastasis in mice (107). Consumption of high carbohydrate or high fat diets has been shown to increase breast cancer progression (108) in association with increased levels of specific cytokines, including IL-12 (109), osteopontin (110) or TIMPs $(111,112)$. Future studies should incorporate precision nutrition approaches to account for individual differences in metabolic, inflammatory and/or immune responses to dietary interventions. Sources of heterogeneity in response to dietary factors include genetic, epigenetic, and microbiome differences. For example, the D.I.E.T project focused on identifying optimized diets to augment immunotherapies, particularly through microbiome manipulation (113). Studies such as D.I.E.T. reinforce the need for precision nutrition efforts to address research gaps (114) and provide new opportunities to use food as medicine $(115,116)$ to break immune and inflammation-driven obesity-breast cancer links.

\section{MEDIATORS OF VASCULAR INTEGRITY THAT ENHANCE OBESITY-BREAST CANCER LINKS}

Tumor vasculature is an important component of the tumor microenvironment and is involved in various molecular processes (117). Tumor growth and proliferation require new blood vessels that can supply ample nutrients and oxygen and provide transport for metabolic waste. Moreover, metastasis requires tumor cells to infiltrate the vasculature to colonize distant sites $(118,119)$ (Figure 1). Angiogenesis, stimulated by TNF $\alpha$, VEGF, and IL-8 (120), recruits new blood vessels during cancer initiation, progression and metastasis (121). New blood vessel formation is the first step in the metastatic cascade, and a critical mechanistic target triggered by inadequate oxygen supply (122). Hypoxia in the microenvironment stabilizes hypoxiainducible factor (HIF)-1 $\alpha$, which regulates numerous metabolic, angiogenic, and apoptotic genes. HIF- $1 \alpha$ enhances the expression of the chemokine receptor CXCR4 and interacts with the lipoxygenase pathway (122). The hypoxia that develops within a tumor promotes the malignant phenotype as the genomic stability of the growing tumor decreases $(120,122)$.

Intra-tumoral blood vessels display vessel dilation, high proliferation rate and increased permeability $(118,119,122)$. Highly vascular tumors are associated with a greater number of macrophages (123). Obesity is associated with activation of the NLRC4 inflammasome, enrichment of TAMs, elevated IL-1 $\beta$, and increased angiogenesis $(124,125)$. The high levels of IL-1 $\beta$ in response to obesity induce the expression of Angiopoietin-like 4 (ANGPTL4) from primary adipocytes in a manner dependent on NF- $\mathrm{KB}$ - and MAPK-activation, which is enhanced by hypoxia (125). Studies in mouse models have shown that adipocytederived ANGPTL4 drives BC progression under obese conditions and it could be a potential therapeutic target for treating obese BC patients (125). Microvessel density is a major prognostic factor for metastatic cancer, and a measure of angiogenesis $(122,123)$. For a tumor to gain metastatic potential, it must undergo an "angiogenic switch," which occurs when factors enhancing angiogenic processes exceed the antiangiogenic factors of a tumor (126).

\section{Vasculature-Dependent Targets for Intervention}

Dysfunctional tumor vasculature limits chemotherapy delivery to tumors. Additionally, a lack of sufficient oxygen delivery promotes hypoxia and acidification which ultimately leads to the development of more aggressive tumors. Physical exercise improves intratumoral vascularization and perfusion. Regular exercise is associated with lasting tumor vascular maturity, reduced vascular resistance, and increased vascular conductance. Thus, regular exercise is linked to reducing intratumoral hypoxia favoring the accessibility of circulating immune cells to the tumor microenvironment, inhibiting tumor development and improving cancer treatment (127).

Fatty acids, such as arachidonic acid and omega-3 fatty acids, have been found to have a role in breast cancer $(128,129)$. An increased expression of arachidonic acid in breast cancer tissues is strongly correlated with an enhanced mTORC1 and mTORC2 signaling (128). Furthermore, arachidonic acid-activated mTOR plays a primary role in angiogenesis and tumorigenesis (128). The expression of VEGF and cytosolic phospholipase A2 (cPLA2) are also increased by arachidonic acid (128). Omega-3 fatty acids have been linked to protective roles in breast cancer progression, such as the inhibition of angiogenesis and metastasis (Figure 1). 
Additionally, several studies have suggested an association between a higher omega-3 intake and a lower risk of breast cancer $(129,130)$. Supplementation of omega-3 fatty acids in women undergoing surgery for locally advanced, invasive carcinoma resulted in decreased expression of both Ki-67 and VEGF compared to a control group (130). Furthermore, the omega-3 fatty acid supplementation group displayed a longer disease-free survival and overall survival (130).

Oxidative stress occurs due to an imbalance between antioxidant defenses in the body and production of reactive species, such as reactive oxygen species (ROS) or reaction nitrogen species (RNS) (131). This stress has been suggested as an important factor in tumor initiation and progression. Nitric oxide synthases (NOS), such as endothelial NOS, can generate RNS, and have been shown to modulate processes including inflammation, angiogenesis and metastasis (131). Human breast cancer cells displayed activation of the EGFR and ERK pathways when treated with nitric oxide, and ultimately showed an increase in invasive potential (132). In one study using rats with mammary tumors, a diet enriched with PUFAs resulted in tumor regression due to improved drug delivery. The observed tumor regression was associated with decreased activation of endothelial NOS, which normalized the vasculature of the mammary tumors (133).

\section{OBESITY LINKS TO BREAST CANCER METASTASIS AND INTERVENTIONS TO DISRUPT THE LINKS}

Metastasis is linked to $90 \%$ of tumor-related deaths in BC patients (134), and $\sim 30 \%$ of patients develop metastases at some point after diagnosis (135). Obese patients have larger primary tumors at diagnosis and increased risk of lymph node metastasis for all BC subtypes (136). Obesity decreases the time from primary diagnosis to metastatic disease, and mouse models have confirmed that lung metastases are more prevalent in obese mice compared with lean mice $(137,138)$. Given that increased metastatic potential is associated with obesity, uncovering the mechanisms of this relationship is now a major focus of research.

Adipose stem cells (ASCs), abundant in adipose stromal tissue, can become osteoblasts, chondrocytes, myocytes, or monocytes, and are a new player in obesogenic metastasis (134, 139), specifically in TNBC. ASCs from obese mice increase tumor microenvironment leptin levels, directly promoting metastasis rather than enhancing primary tumor growth (134). Chroniclow-grade, obesity-associated inflammation activates immune cells preparing the metastatic niche (140); which then limits immunosurveillance protections, suppressing CD8+ T-cell function through IL-1 $\beta$, while promoting neutrophil expansion and polarization (141). Neutrophil-mediated mechanisms in lungs of obese mice were specifically shown to result in higher metastatic burden $(138,142)$.

Epithelial-to-mesenchymal transition (EMT) is another mechanism associated with a more invasive and aggressive metastatic phenotype. EMT involves loss of epithelial polarity, de-differentiation, and local invasion (134, 143), but its mechanistic underpinnings have only recently become linked with obesity. For example, Bousquenaud and colleagues demonstrated tumors from mice fed a high-fat diet lost the cell junction protein E-cadherin, but increased expression of mesenchymal markers N-cadherin and vimentin (138). Obesitydriven inflammatory markers (i.e., NF- $\kappa$ B, STAT3, and COX-2) also play a role in EMT $(3,144)$. These emerging mechanisms have begun to reveal the complex relationships between obesity and the metabolic reprogramming of tumor cells that favor metastatic progression. Future interventions strategies will also need to account for the multi-factored contributors, namely inflammation, when addressing this aspect of BC.

\section{DISCUSSION ON CHALLENGES AND GAPS FOR NUTRITIONALLY RELEVANT INTERVENTIONS}

The aggressive biology of the tumor microenvironment metabolically activated by dysregulated adipose tissues in the obese state reduces the efficacy of cancer treatments, posing greater challenges in patient care and disease management. Further investigations are needed to improve early diagnosis and treatment mechanisms to successfully target BC within these patients. Nutrition and physical activity-based interventions that better manage obesity represent viable strategies to break obesity-breast cancer links.

The most recent guidance for adult (19-65 years) daily nutritional intakes includes protein at $10-35 \%$, fat at $20-35 \%$ and total carbohydrates at 45-65\% (145-147). These ranges demonstrate the complexity involved in deciphering what determines a healthy diet/dietary pattern. Dietary Reference Intake (DRI) guidelines classify diet and the role of nutrition in the context of chronic diseases more specifically (148-153), but navigating these extensive reports is a major challenge. Current recommendations focus on making nutritional choices that reflect overall healthy eating patterns to reduce chronic disease incidence (154), including limiting refined carbohydrates/sugars to $25 \%$ of total daily intake, and levels of cholesterol, trans- and saturated fatty acids to, "as low as possible while consuming a nutritionally adequate diet" $(147,155)$.

A substantial number of preclinical $(47,96,156-163)$ and epidemiological (164-170) studies have shown the impact of diets, that result in obesity, with different macronutrient compositions on BC development and disease outcomes. For example, several studies have demonstrated the negative impacts on overall health from diets high in fat content, including cancer outcomes from consumption of Western-style diets, high in poor quality carbohydrates (refined and simple sugars) and saturated fats (171-176). Comparatively, there is still controversy regarding high protein (thus, lower carbs and fat) diets. Animal and human studies have demonstrated the benefits of high protein content (at intakes of 23-69\%) on slowing or inhibiting mammary tumor formation, reducing disease progression, improving chemosensitivity, and extending survival/lifespan (177-179). In contrast, Park et al. correlated higher acid load, presumably from high protein intake and concomitant high phosphorus consumption, with higher ER- 
BC risk (180) and other lifetime cancer risks $(181,182)$ in the Sister Study. The Mediterranean-style diet involves consumption of high levels of protein and fat, but the sources are restricted to lean, non-processed (low red meat) proteins and 'healthier' forms of fat, with increased fiber content from fruits, vegetables and whole grains. This dietary pattern has been associated with lower BC risk, specifically through microbiome population modifications (i.e., Lactobacillus) that diminish cancer-promoting mechanisms, like oxidative stress, in the mammary gland $(174,183)$. However, there are still significant gaps at both the population and individual level concerning dietary guidelines to maintain health. Several reviews and investigations have focused on defining appropriate nutrient intakes for improved BC patient outcomes (100, 166, 184186). Yet, changes in life-style and food choices represent a challenge for BC patients; for example, Shi et al. found that newly diagnosed with BC consistently consume excessive fat and slightly increased consumption of fruits and vegetables following diagnosis (166). These and other findings stress the need of incorporating nutritional and psychosocial counseling to better manage diverse ramifications of diagnosis and treatment of BC patient to increase recovery rate and overall health.

\section{CONCLUSIONS}

In conclusion, there has been tremendous progress in understanding the mechanisms underlying the obesity-BC link. While there is more to learn about the biology of this link, emphasis should be placed on translating our knowledge into

\section{REFERENCES}

1. Ford NA, Devlin KL, Lashinger LM, Hursting SD. Deconvoluting the Obesity and Breast Cancer Link: Secretome, Soil and Seed Interactions. J Mammary Gland Biol Neoplasia (2013) 18(3):267-75. doi: 10.1007/s10911013-9301-9

2. WHO. Obesity and Overweight 2020. Geneva: World Health Organization (2020). Available at: https://www.who.int/news-room/fact-sheets/detail/ obesity-and-overweight.

3. Gérard C, Brown KA. Obesity and breast cancer - Role of estrogens and the molecular underpinnings of aromatase regulation in breast adipose tissue. Mol Cell Endocrinol (2018) 466:15-30. doi: 10.1016/j.mce.2017.09.014

4. Kelly T, Yang W, Chen CS, Reynolds K, He J. Global burden of obesity in 2005 and projections to 2030. Int J Obes (2008) 32(9):1431-7. doi: 10.1038/ ijo. 2008.102

5. Center for Disease Control and Prevention (CDC) HW. Nutrition, and Physical Activity. The Health Effects of Overweight and Obesity (2020) Atlanta, GA. Available at: https://www.cdc.gov/healthyweight/effects/index.html.

6. Bray F, Ferlay J, Soerjomataram I, Siegel RL, Torre LA, Jemal A. Global cancer statistics 2018: GLOBOCAN estimates of incidence and mortality worldwide for 36 cancers in 185 countries. CA Cancer J Clin (2018) 68 (6):394-424. doi: 10.3322/caac. 21492

7. Herschkowitz JI, Simin K, Weigman VJ, Mikaelian I, Usary J, Hu Z, et al. Identification of conserved gene expression features between murine mammary carcinoma models and human breast tumors. Genome Biol (2007) 8(5):R76. doi: 10.1186/gb-2007-8-5-r76

8. Harbeck N, Penault-Llorca F, Cortes J, Gnant M, Houssami N, Poortmans P, et al. Breast cancer. Nat Rev Dis Primers (2019) 5(1):66. doi: 10.1038/s41572019-0111-2 effective strategies to reduce the obesity-associated burden of $\mathrm{BC}$ in women. Emerging initiatives in precision nutrition focused on understanding why metabolism and nutrition requirements differ between individuals - considering host factors (i.e., genetic, epigenetic, microbiome) and environmental factors (i.e., diet, physical activity, mental health, and direct environmental exposures) - will enable more personalized, targeted guidance for optimal mechanism-based nutritional strategies to reduce obesity-driven BC (114).

\section{AUTHOR CONTRIBUTIONS}

DS and XMBM outlined the topics discussed in this review. JM, $\mathrm{MC}$, and ED contributed to writing specific sections. $\mathrm{SH}, \mathrm{XMBM}$, and DS provided critical revision of the article. XMBM designed the art work for Figure 1. All authors contributed to the article and approved the submitted version.

\section{FUNDING}

XMBM is supported by the Marilyn Gentry Fellowship Program in Nutrition and Cancer from the American Institute for Cancer Research-World Cancer Research Fund (AICR/WCRF) and the University of North Carolina. DS is supported by the Nutrition Research Institute Faculty Development Program. SH is supported by grants from the National Cancer Institute (NCIR35CA197627) and from the Breast Cancer Research Foundation (BCRF\#18073).

9. Perou CM, Sørlie T, Eisen MB, van de Rijn M, Jeffrey SS, Rees CA, et al Molecular portraits of human breast tumours. Nature (2000) 406 (6797):747-52. doi: 10.1038/35021093

10. Shiovitz S, Korde LA. Genetics of breast cancer: a topic in evolution. Ann Oncol: Off J Eur Soc Med Oncol (2015) 26(7):1291-9. doi: 10.1093/annonc/ mdv022

11. Danaei G, Vander Hoorn S, Lopez AD, Murray CJ, Ezzati M. Causes of cancer in the world: comparative risk assessment of nine behavioural and environmental risk factors. Lancet (London England) (2005) 366 (9499):1784-93. doi: 10.1016/s0140-6736(05)67725-2

12. Rose DP, Vona-Davis L. Interaction between menopausal status and obesity in affecting breast cancer risk. Maturitas (2010) 66(1):33-8. doi: 10.1016/ j.maturitas.2010.01.019

13. Agurs-Collins T, Ross SA, Dunn BK. The Many Faces of Obesity and Its Influence on Breast Cancer Risk. Front Oncol (2019) 9:765. doi: 10.3389/ fonc.2019.00765

14. Renehan AG, Tyson M, Egger M, Heller RF, Zwahlen M. Body-mass index and incidence of cancer: a systematic review and meta-analysis of prospective observational studies. Lancet (London England) (2008) 371 (9612):569-78. doi: 10.1016/s0140-6736(08)60269-x

15. Suzuki R, Orsini N, Saji S, Key TJ, Wolk A. Body weight and incidence of breast cancer defined by estrogen and progesterone receptor status-a meta-analysis. Int J Cancer (2009) 124(3):698-712. doi: 10.1002/ijc. 23943

16. Dietze EC, Chavez TA, Seewaldt VL. Obesity and Triple-Negative Breast Cancer: Disparities, Controversies, and Biology. Am J Pathol (2018) 188 (2):280-90. doi: 10.1016/j.ajpath.2017.09.018

17. Bandera EV, Maskarinec G, Romieu I, John EM. Racial and ethnic disparities in the impact of obesity on breast cancer risk and survival: a global 
perspective. Adv Nutr (Bethesda Md) (2015) 6(6):803-19. doi: 10.3945/ an.115.009647

18. Carey LA, Perou CM, Livasy CA, Dressler LG, Cowan D, Conway K, et al. Race, breast cancer subtypes, and survival in the Carolina Breast Cancer Study. Jama (2006) 295(21):2492-502. doi: 10.1001/jama.295.21.2492

19. Santa-Maria CA, Yan J, Xie X-J, Euhus DM. Aggressive estrogen-receptorpositive breast cancer arising in patients with elevated body mass index. Int $J$ Clin Oncol (2015) 20(2):317-23. doi: 10.1007/s10147-014-0712-4

20. Chan DS, Norat T. Obesity and breast cancer: not only a risk factor of the disease. Curr Treat Options Oncol (2015) 16(5):22. doi: 10.1007/s11864-0150341-9

21. Argolo DF, Hudis CA, Iyengar NM. The Impact of Obesity on Breast Cancer. Curr Oncol Rep (2018) 20(6):47. doi: 10.1007/s11912-018-0688-8

22. Lee K, Kruper L, Dieli-Conwright CM, Mortimer JE. The Impact of Obesity on Breast Cancer Diagnosis and Treatment. Curr Oncol Rep (2019) 21 (5):41-. doi: 10.1007/s11912-019-0787-1

23. Rossi EL, de Angel RE, Bowers LW, Khatib SA, Smith LA, Van Buren E, et al. Obesity-Associated Alterations in Inflammation, Epigenetics, and Mammary Tumor Growth Persist in Formerly Obese Mice. Cancer Prev Res (Phila) (2016) 9(5):339-48. doi: 10.1158/1940-6207.CAPR-15-0348

24. Goodwin PJ, Ennis M, Pritchard KI, Trudeau ME, Koo J, Taylor SK, et al. Insulin- and Obesity-Related Variables in Early-Stage Breast Cancer: Correlations and Time Course of Prognostic Associations. J Clin Oncol (2012) 30(2):164-71. doi: 10.1200/JCO.2011.36.2723

25. Haywood NJ, Slater TA, Matthews CJ, Wheatcroft SB. The insulin like growth factor and binding protein family: Novel therapeutic targets in obesity \& diabetes. Mol Metab (2019) 19:86-96. doi: 10.1016/ j.molmet.2018.10.008

26. Cheng T-YD, Omilian AR, Yao S, Sanchez PV, Polk LZ, Zhang W, et al. Body fatness and mTOR pathway activation of breast cancer in the Women's Circle of Health Study. NPJ Breast Cancer (2020) 6:45-. doi: 10.1038/s41523020-00187-4

27. Allard JB, Duan C. IGF-Binding Proteins: Why Do They Exist and Why Are There So Many? Front Endocrinol (Lausanne) (2018) 9:117. doi: 10.3389/ fendo.2018.00117

28. Engin A. Obesity-associated Breast Cancer: Analysis of risk factors. In: AB Engin and A Engin, editors. Obesity and Lipotoxicity. Cham: Springer International Publishing (2017). p. 571-606.

29. Bowers LW, Cavazos DA, Maximo IX, Brenner AJ, Hursting SD, deGraffenried LA. Obesity enhances nongenomic estrogen receptor crosstalk with the PI3K/Akt and MAPK pathways to promote in vitro measures of breast cancer progression. Breast Cancer Res: BCR (2013) 15(4): R59. doi: $10.1186 / \mathrm{bcr} 3453$

30. Giovannucci E, Harlan DM, Archer MC, Bergenstal RM, Gapstur SM, Habel LA, et al. Diabetes and cancer: a consensus report. Diabetes Care (2010) 33 (7):1674-85. doi: 10.2337/dc10-0666

31. Dankner R, Shanik MH, Keinan-Boker L, Cohen C, Chetrit A. Effect of elevated basal insulin on cancer incidence and mortality in cancer incident patients: the Israel GOH 29-year follow-up study. Diabetes Care (2012) 35 (7):1538-43. doi: 10.2337/dc11-1513

32. Hemkens LG, Grouven U, Bender R, Günster C, Gutschmidt S, Selke GW, et al. Risk of malignancies in patients with diabetes treated with human insulin or insulin analogues: a cohort study. Diabetologia (2009) 52(9):173244. doi: 10.1007/s00125-009-1418-4

33. Nam S, Park S, Park HS, Kim S, Kim JY, Kim SI. Association Between Insulin Resistance and Luminal B Subtype Breast Cancer in Postmenopausal Women. Medicine (2016) 95(9):e2825. doi: 10.1097/MD.0000000000002825

34. Key T, Appleby P, Barnes I, Reeves G. Endogenous sex hormones and breast cancer in postmenopausal women: reanalysis of nine prospective studies. J Natl Cancer Inst (2002) 94(8):606-16. doi: 10.1093/jnci/94.8.606

35. Bulun SE, Chen D, Moy I, Brooks DC, Zhao H. Aromatase, breast cancer and obesity: a complex interaction. Trends Endocrinol Metab (2012) 23(2):83-9. doi: 10.1016/j.tem.2011.10.003

36. Cleary MP, Grossmann ME. Minireview: Obesity and breast cancer: the estrogen connection. Endocrinology (2009) 150(6):2537-42. doi: 10.1210/ en.2009-0070

37. Ahn J, Schatzkin A, Lacey JV Jr., Albanes D, Ballard-Barbash R, Adams KF, et al. Adiposity, adult weight change, and postmenopausal breast cancer risk.
Arch Internal Med (2007) 167(19):2091-102. doi: 10.1001/ archinte.167.19.2091

38. Han YM, Kang GM, Byun K, Ko HW, Kim J, Shin M-S, et al. Leptinpromoted cilia assembly is critical for normal energy balance. J Clin Invest (2014) 124(5):2193-7. doi: 10.1172/JCI69395

39. Vaisse C, Reiter JF, Berbari NF. Cilia and Obesity. Cold Spring Harbor Perspect Biol (2017) 9(7):a028217. doi: 10.1101/cshperspect.a028217

40. Lee JM, Kim SR, Yoo SJ, Hong OK, Son HS, Chang SA. The relationship between adipokines, metabolic parameters and insulin resistance in patients with metabolic syndrome and type 2 diabetes. J Int Med Res (2009) 37 (6):1803-12. doi: 10.1177/147323000903700616

41. Ozenoglu A, Balci H, Ugurlu S, Caglar E, Uzun H, Sarkis C, et al. The relationships of leptin, adiponectin levels and paraoxonase activity with metabolic and cardiovascular risk factors in females treated with psychiatric drugs. Clinics (Sao Paulo Brazil) (2008) 63(5):651-60. doi: 10.1590/s180759322008000500014

42. Frühbeck G, Catalán V, Rodríguez A, Gómez-Ambrosi J. Adiponectin-leptin ratio: A promising index to estimate adipose tissue dysfunction. Relation with obesity-associated cardiometabolic risk. Adipocyte (2018) 7(1):57-62. doi: 10.1080/21623945.2017.1402151

43. Mullen M, Gonzalez-Perez RR. Leptin-Induced JAK/STAT Signaling and Cancer Growth. Vaccines (Basel) (2016) 4(3):26. doi: 10.3390/ vaccines 4030026

44. Pérez-Pérez A, Vilariño-García T, Fernández-Riejos P, Martín-González J, Segura-Egea JJ, Sánchez-Margalet V. Role of leptin as a link between metabolism and the immune system. Cytokine Growth Fact Rev (2017) 35:71-84. doi: 10.1016/j.cytogfr.2017.03.001

45. Ollberding NJ, Kim Y, Shvetsov YB, Wilkens LR, Franke AA, Cooney RV, et al. Prediagnostic leptin, adiponectin, C-reactive protein, and the risk of postmenopausal breast cancer. Cancer Prev Res (Phila) (2013) 6(3):188-95. doi: 10.1158/1940-6207.CAPR-12-0374

46. Nyasani E, Munir I, Perez M, Payne K, Khan S. Linking obesity-induced leptin-signaling pathways to common endocrine-related cancers in women. Endocrine (2019) 63(1):3-17. doi: 10.1007/s12020-018-1748-4

47. Dunlap SM, Chiao LJ, Nogueira L, Usary J, Perou CM, Varticovski L, et al. Dietary energy balance modulates epithelial-to-mesenchymal transition and tumor progression in murine claudin-low and basal-like mammary tumor models. Cancer Prev Res (Phila) (2012) 5(7):930-42. doi: 10.1158/19406207.CAPR-12-0034

48. Dallal CM, Brinton LA, Matthews CE, Pfeiffer RM, Hartman TJ, Lissowska J, et al. Association of Active and Sedentary Behaviors with Postmenopausal Estrogen Metabolism. Med Sci Sports Exerc (2016) 48(3):439-48. doi: 10.1249/MSS.0000000000000790

49. Oh H, Arem H, Matthews CE, Wentzensen N, Reding KW, Brinton LA, et al. Sitting, physical activity, and serum oestrogen metabolism in postmenopausal women: the Women's Health Initiative Observational Study. Br J Cancer (2017) 117(7):1070-8. doi: 10.1038/bjc.2017.268

50. Pizot C, Boniol M, Mullie P, Koechlin A, Boniol M, Boyle P, et al. Physical activity, hormone replacement therapy and breast cancer risk: A metaanalysis of prospective studies. Eur J Cancer (Oxford England: 1990) (2016) 52:138-54. doi: 10.1016/j.ejca.2015.10.063

51. Cox CE. Role of Physical Activity for Weight Loss and Weight Maintenance. Diabetes Spectr (2017) 30(3):157-60. doi: 10.2337/ds17-0013

52. National Cancer Institute (NCI). Physical Activity and Cancer. NCI at the National Institutes of Health, Bethesda, MD (2020). Available at: https:// www.cancer.gov/about-cancer/causes-prevention/risk/obesity/physicalactivity-fact-sheet.

53. Papadimitriou N, Dimou N, Tsilidis KK, Banbury B, Martin RM, Lewis SJ, et al. Physical activity and risks of breast and colorectal cancer: a Mendelian randomisation analysis. Nat Commun (2020) 11(1):597. doi: 10.1038/ s41467-020-14389-8

54. Moore SC, Lee IM, Weiderpass E, Campbell PT, Sampson JN, Kitahara CM, et al. Association of Leisure-Time Physical Activity With Risk of 26 Types of Cancer in 1.44 Million Adults. JAMA Internal Med (2016) 176(6):816-25. doi: 10.1001/jamainternmed.2016.1548

55. Juiz-Valiña P, Pena-Bello L, Cordido M, Outeiriño-Blanco E, Pértega S, Varela-Rodriguez B, et al. Altered GH-IGF-1 Axis in Severe Obese Subjects is Reversed after Bariatric Surgery-Induced Weight Loss and Related with 
Low-Grade Chronic Inflammation. J Clin Med (2020) 9(8):2614. doi: $10.3390 / \mathrm{jcm} 9082614$

56. Fontana L, Weiss EP, Villareal DT, Klein S, Holloszy JO. Long-term effects of calorie or protein restriction on serum IGF-1 and IGFBP-3 concentration in humans. Aging Cell (2008) 7(5):681-7. doi: 10.1111/j.1474-9726.2008.00417.x

57. Kazemi A, Speakman JR, Soltani S, Djafarian K. Effect of calorie restriction or protein intake on circulating levels of insulin like growth factor I in humans: A systematic review and meta-analysis. Clin Nutr (2020) 39 (6):1705-16. doi: 10.1016/j.clnu.2019.07.030

58. Yang HF, Lin XJ, Wang XH. [Effects of aerobic exercise plus diet control on serum levels of total IGF-1 and IGF-1 binding protein-3 in female obese youths and adolescents]. Zhongguo Ying Yong Sheng Li Xue Za Zhi (2018) 34 (1):78-82. doi: $10.12047 /$ j.cjap.5571.2018.020

59. Mason C, Xiao L, Duggan C, Imayama I, Foster-Schubert KE, Kong A, et al. Effects of dietary weight loss and exercise on insulin-like growth factor-I and insulin-like growth factor-binding protein-3 in postmenopausal women: a randomized controlled trial. Cancer Epidemiol Biomarkers Prev (2013) 22 (8):1457-63. doi: 10.1158/1055-9965.EPI-13-0337

60. Kelly L, Holmberg PM, Schroeder ET, Loza A, Lin X, Moody A, et al. Effect of home-based strength training program on IGF-I, IGFBP-1 and IGFBP-3 in obese Latino boys participating in a 16-week randomized controlled trial. J Pediatr Endocrinol Metabol: JPEM (2019) 32(10):1121-9. doi: 10.1515/ jpem-2019-0073

61. Al-Regaiey K, Alshubrami S, Al-Beeshi I, Alnasser T, Alwabel A, Al-Beladi $\mathrm{H}$, et al. Effects of gastric sleeve surgery on the serum levels of GH, IGF-1 and IGF-binding protein 2 in healthy obese patients. BMC Gastroenterol (2020) 20(1):199. doi: 10.1186/s12876-020-01309-9

62. Bowers LW, Rossi EL, O'Flanagan CH, deGraffenried LA, Hursting SD. The Role of the Insulin/IGF System in Cancer: Lessons Learned from Clinical Trials and the Energy Balance-Cancer Link. Front Endocrinol (Lausanne) (2015) 6:77. doi: 10.3389/fendo.2015.00077

63. de Groot S, Vreeswijk MP, Welters MJ, Gravesteijn G, Boei JJ, Jochems A, et al. The effects of short-term fasting on tolerance to (neo) adjuvant chemotherapy in HER2-negative breast cancer patients: a randomized pilot study. BMC Cancer (2015) 15:652. doi: 10.1186/s12885-015-1663-5

64. Bauersfeld SP, Kessler CS, Wischnewsky M, Jaensch A, Steckhan N, Stange $\mathrm{R}$, et al. The effects of short-term fasting on quality of life and tolerance to chemotherapy in patients with breast and ovarian cancer: a randomized cross-over pilot study. BMC Cancer (2018) 18(1):476. doi: 10.1186/s12885018-4353-2

65. Yamamoto M, Iguchi G, Fukuoka H, Suda K, Bando H, Takahashi M, et al. SIRT1 regulates adaptive response of the growth hormone-insulin-like growth factor-I axis under fasting conditions in liver. Proc Natl Acad Sci United States America (2013) 110(37):14948-53. doi: 10.1073/ pnas. 1220606110

66. Lee C, Safdie FM, Raffaghello L, Wei M, Madia F, Parrella E, et al. Reduced levels of IGF-I mediate differential protection of normal and cancer cells in response to fasting and improve chemotherapeutic index. Cancer Res (2010) 70(4):1564-72. doi: 10.1158/0008-5472.can-09-3228

67. Nogueira LM, Dunlap SM, Ford NA, Hursting SD. Calorie restriction and rapamycin inhibit MMTV-Wnt-1 mammary tumor growth in a mouse model of postmenopausal obesity. Endocr Relat Cancer (2012) 19(1):57-68. doi: 10.1530/erc-11-0213

68. Jin J, Qiu S, Wang P, Liang X, Huang F, Wu H, et al. Cardamonin inhibits breast cancer growth by repressing HIF- $1 \alpha$-dependent metabolic reprogramming. J Exp Clin Cancer Res: CR (2019) 38(1):377. doi: 10.1186/ s13046-019-1351-4

69. Peng X, Chang H, Gu Y, Chen J, Yi L, Xie Q, et al. 3,6-Dihydroxyflavone Suppresses Breast Carcinogenesis by Epigenetically Regulating miR-34a and miR-21. Cancer Prev Res (Phila) (2015) 8(6):509-17. doi: 10.1158/19406207.Capr-14-0357

70. Colotta F, Allavena P, Sica A, Garlanda C, Mantovani A. Cancer-related inflammation, the seventh hallmark of cancer: links to genetic instability. Carcinogenesis (2009) 30(7):1073-81. doi: 10.1093/carcin/bgp127

71. Del Prete A AP, Santoro G, Fumarulo R, Corsi MM, Mantovani A. Molecular pathways in cancer-related inflammation. Biochem Med (Zagreb) (2011) 21(3):264-75. doi: 10.11613/bm.2011.036
72. Hanahan D, Weinberg RA. Hallmarks of cancer: the next generation. Cell (2011) 144(5):646-74. doi: 10.1016/j.cell.2011.02.013

73. Crouch M, Al-Shaer A, Shaikh SR. Hormonal Dysregulation and Unbalanced Specialized Pro-Resolving Mediator Biosynthesis Contribute toward Impaired B Cell Outcomes in Obesity. Mol Nutr Food Res (2021) 65 (1):e1900924. doi: 10.1002/mnfr.201900924

74. Rius J, Guma M, Schachtrup C, Akassoglou K, Zinkernagel AS, Nizet V, et al. NF-kappaB links innate immunity to the hypoxic response through transcriptional regulation of HIF-1alpha. Nature (2008) 453(7196):807-11. doi: 10.1038/nature06905

75. Sica A. Role of tumour-associated macrophages in cancer-related inflammation. Exp Oncol (2010) 32(3):153-8. doi: 10.1007/978-1-46140662-4_11

76. Hagemann T, Lawrence T, McNeish I, Charles KA, Kulbe H, Thompson RG, et al. "Re-educating" tumor-associated macrophages by targeting NFkappaB. J Exp Med (2008) 205(6):1261-8. doi: 10.1084/jem.20080108

77. Stewart DA, Yang Y, Makowski L, Troester MA. Basal-like breast cancer cells induce phenotypic and genomic changes in macrophages. Mol Cancer Res (2012) 10(6):727-38. doi: 10.1158/1541-7786.MCR-11-0604

78. Hollmen M, Roudnicky F, Karaman S, Detmar M. Characterization of macrophage-cancer cell crosstalk in estrogen receptor positive and triplenegative breast cancer. Sci Rep (2015) 5:9188. doi: 10.1038/srep09188

79. Dinarello CA. Historical insights into cytokines. Eur J Immunol (2007) 37 (Suppl 1):S34-45. doi: 10.1002/eji.200737772

80. Karin M. Nuclear factor-kappaB in cancer development and progression. Nature (2006) 441(7092):431-6. doi: 10.1038/nature04870

81. Bukowski RM, Olencki T, McLain D, Finke JH. Pleiotropic effects of cytokines: clinical and preclinical studies. Stem Cells (1994) 12(Suppl 1):129-40. discussion 40-1.

82. Daghestani HN, Kraus VB. Inflammatory biomarkers in osteoarthritis. Osteoarthr Cartil (2015) 23(11):1890-6. doi: 10.1016/j.joca.2015.02.009

83. Lappas M. Activation of inflammasomes in adipose tissue of women with gestational diabetes. Mol Cell Endocrinol (2014) 382(1):74-83. doi: 10.1016/ j.mce.2013.09.011

84. Lu H, Ouyang W, Huang C. Inflammation, a key event in cancer development. Mol Cancer Res (2006) 4(4):221-33. doi: 10.1158/15417786.MCR-05-0261

85. Chin AR, Wang SE. Cytokines driving breast cancer stemness. Mol Cell Endocrinol (2014) 382(1):598-602. doi: 10.1016/j.mce.2013.03.024

86. Ma B, Hottiger MO. Crosstalk between Wnt/beta-Catenin and NF-kappaB Signaling Pathway during Inflammation. Front Immunol (2016) 7:378. doi: $10.3389 /$ fimmu. 2016.00378

87. Jiang X, Shapiro DJ. The immune system and inflammation in breast cancer. Mol Cell Endocrinol (2014) 382(1):673-82. doi: 10.1016/j.mce.2013.06.003

88. Ono M. Molecular links between tumor angiogenesis and inflammation: inflammatory stimuli of macrophages and cancer cells as targets for therapeutic strategy. Cancer Sci (2008) 99(8):1501-6. doi: 10.1111/j.13497006.2008.00853.x

89. Karki R, Kanneganti TD. Diverging inflammasome signals in tumorigenesis and potential targeting. Nat Rev Cancer (2019) 19(4):197-214. doi: 10.1038/ s41568-019-0123-y

90. Whiteside TL. Regulatory T cell subsets in human cancer: are they regulating for or against tumor progression? Cancer Immunol Immunother (2014) 63 (1):67-72. doi: 10.1007/s00262-013-1490-y

91. Gray MJ, Gong J, Hatch MM, Nguyen V, Hughes CC, Hutchins JT, et al. Phosphatidylserine-targeting antibodies augment the anti-tumorigenic activity of anti-PD-1 therapy by enhancing immune activation and downregulating pro-oncogenic factors induced by T-cell checkpoint inhibition in murine triple-negative breast cancers. Breast Cancer Res (2016) 18(1):50. doi: 10.1186/s13058-016-0708-2

92. Chaib M, Chauhan SC, Makowski L. Friend or Foe? Recent Strategies to Target Myeloid Cells in Cancer. Front Cell Dev Biol (2020) 8:3516. doi: $10.3389 /$ fcell.2020.00351

93. Fleming JM, Miller TC, Kidacki M, Ginsburg E, Stuelten CH, Stewart DA, et al. Paracrine interactions between primary human macrophages and human fibroblasts enhance murine mammary gland humanization in vivo. Breast Cancer Res (2012) 14(3):R97. doi: 10.1186/bcr3215 
94. Dias JA, Fredrikson GN, Ericson U, Gullberg B, Hedblad B, Engström G, et al. Low-Grade Inflammation, Oxidative Stress and Risk of Invasive PostMenopausal Breast Cancer - A Nested Case-Control Study from the Malmö Diet and Cancer Cohort. PloS One (2016) 11(7):e0158959. doi: 10.1371/ journal.pone. 0158959

95. Kumar R, Litoff EJ, Boswell WT, Baldwin WS. High fat diet induced obesity is mitigated in Cyp3a-null female mice. Chem Biol Interact (2018) 289:12940. doi: 10.1016/j.cbi.2018.05.001

96. Wang K, Chen X, Ward SC, Liu Y, Ouedraogo Y, Xu C, et al. CYP2A6 is associated with obesity: studies in human samples and a high fat diet mouse model. Int J Obes (Lond) (2019) 43(3):475-86. doi: 10.1038/s41366-0180037-x

97. Picon-Ruiz M, Morata-Tarifa C, Valle-Goffin JJ, Friedman ER, Slingerland JM. Obesity and adverse breast cancer risk and outcome: Mechanistic insights and strategies for intervention. CA Cancer J Clin (2017) 67 (5):378-97. doi: 10.3322/caac.21405

98. Grimm EA, Sikora AG, Ekmekcioglu S. Molecular pathways: inflammationassociated nitric-oxide production as a cancer-supporting redox mechanism and a potential therapeutic target. Clin Cancer Res (2013) 19(20):5557-63. doi: 10.1158/1078-0432.CCR-12-1554

99. Levano KS, Jung EH, Kenny PA. Breast cancer subtypes express distinct receptor repertoires for tumor-associated macrophage derived cytokines. Biochem Biophys Res Commun (2011) 411(1):107-10. doi: 10.1016/ j.bbrc.2011.06.102

100. Seiler A, Chen MA, Brown RL, Fagundes CP. Obesity, Dietary Factors, Nutrition, and Breast Cancer Risk. Curr Breast Cancer Rep (2018) 10(1):1427. doi: $10.1007 / \mathrm{s} 12609-018-0264-0$

101. Monk JM, Turk HF, Liddle DM, De Boer AA, Power KA, Ma DW, et al. n-3 polyunsaturated fatty acids and mechanisms to mitigate inflammatory paracrine signaling in obesity-associated breast cancer. Nutrients (2014) 6 (11):4760-93. doi: 10.3390/nu6114760

102. Itoh M, Suganami T, Satoh N, Tanimoto-Koyama K, Yuan X, Tanaka M, et al. Increased adiponectin secretion by highly purified eicosapentaenoic acid in rodent models of obesity and human obese subjects. Arterioscler Thromb Vasc Biol (2007) 27(9):1918-25. doi: 10.1161/ATVBAHA.106. 136853

103. Rossmeisl M, Jilkova ZM, Kuda O, Jelenik T, Medrikova D, Stankova B, et al. Metabolic effects of n-3 PUFA as phospholipids are superior to triglycerides in mice fed a high-fat diet: possible role of endocannabinoids. PloS One (2012) 7(6):e38834. doi: 10.1371/journal.pone.0038834

104. Rossmeisl M, Medrikova D, van Schothorst EM, Pavlisova J, Kuda O, Hensler M, et al. Omega-3 phospholipids from fish suppress hepatic steatosis by integrated inhibition of biosynthetic pathways in dietary obese mice. Biochim Biophys Acta (2014) 1841(2):267-78. doi: 10.1016/ j.bbalip.2013.11.010

105. MacLennan MB, Clarke SE, Perez K, Wood GA, Muller WJ, Kang JX, et al. Mammary tumor development is directly inhibited by lifelong $n-3$ polyunsaturated fatty acids. J Nutr Biochem (2013) 24(1):388-95. doi: 10.1016/j.jnutbio.2012.08.002

106. Leslie MA, Abdelmagid SA, Perez K, Muller WJ, Ma DW. Mammary tumour development is dose-dependently inhibited by $\mathrm{n}-3$ polyunsaturated fatty acids in the MMTV-neu(ndl)-YD5 transgenic mouse model. Lipids Health Dis (2014) 13:96. doi: 10.1186/1476-511X-13-96

107. Kanaya N, Adams L, Takasaki A, Chen S. Whole blueberry powder inhibits metastasis of triple negative breast cancer in a xenograft mouse model through modulation of inflammatory cytokines. Nutr Cancer (2014) 66 (2):242-8. doi: 10.1080/01635581.2014.863366

108. Tabung FK, Steck SE, Liese AD, Zhang J, Ma Y, Johnson KC, et al. Patterns of change over time and history of the inflammatory potential of diet and risk of breast cancer among postmenopausal women. Breast Cancer Res Treat (2016) 159(1):139-49. doi: 10.1007/s10549-016-3925-6

109. de Almeida-Souza CB, Antunes MM, Godoy G, Schamber CR, Silva M, Bazotte RB. Interleukin-12 as a biomarker of the beneficial effects of food restriction in mice receiving high fat diet or high carbohydrate diet. Braz J Med Biol Res (2018) 51(12):e7900. doi: 10.1590/1414-431X20187900

110. Lindahl G, Rzepecka A, Dabrosin C. Increased Extracellular Osteopontin Levels in Normal Human Breast Tissue at High Risk of Developing Cancer and Its Association With Inflammatory Biomarkers in situ. Front Oncol (2019) 9:746. doi: 10.3389/fonc.2019.00746

111. Jaworski DM, Sideleva O, Stradecki HM, Langlois GD, Habibovic A, Satish B, et al. Sexually dimorphic diet-induced insulin resistance in obese tissue inhibitor of metalloproteinase-2 (TIMP-2)-deficient mice. Endocrinology (2011) 152(4):1300-13. doi: 10.1210/en.2010-1029

112. Fjaere E, Andersen C, Myrmel LS, Petersen RK, Hansen JB, Tastesen HS, et al. Tissue Inhibitor Of Matrix Metalloproteinase-1 Is Required for HighFat Diet-Induced Glucose Intolerance and Hepatic Steatosis in Mice. PloS One (2015) 10(7):e0132910. doi: 10.1371/journal.pone.0132910

113. Soldati L, Di Renzo L, Jirillo E, Ascierto PA, Marincola FM, De Lorenzo A. The influence of diet on anti-cancer immune responsiveness. J Transl Med (2018) 16(1):75. doi: 10.1186/s12967-018-1448-0

114. Zeisel SH. Precision (Personalized) Nutrition: Understanding Metabolic Heterogeneity. Annu Rev Food Sci Technol (2020) 11:71-92. doi: 10.1146/ annurev-food-032519-051736

115. Adelman J, Haushofer L. Introduction: Food as Medicine, Medicine as Food. J Hist Med Allied Sci (2018) 73(2):127-34. doi: 10.1093/jhmas/jry010

116. Witkamp RF, van Norren K. Let thy food be thy medicine.....when possible. Eur J Pharmacol (2018) 836:102-14. doi: 10.1016/j.ejphar.2018.06.026

117. Kim J. Pericytes in Breast Cancer. Adv Exp Med Biol (2019) 1147:93-107. doi: 10.1007/978-3-030-16908-4_3

118. Guo Y, Zhang S, Yuan H, Song D, Jin S, Guo Z, et al. A platinum(iv) prodrug to defeat breast cancer through disrupting vasculature and inhibiting metastasis. Dalton Trans (2019) 48(11):3571-5. doi: 10.1039/C9DT00335E

119. Wagenblast E, Soto M, Gutiérrez-Ángel S, Hartl CA, Gable AL, Maceli AR, et al. A model of breast cancer heterogeneity reveals vascular mimicry as a driver of metastasis. Nature (2015) 520(7547):358-62. doi: 10.1038/ nature 14403

120. Norton K-A, Jin K, Popel AS. Modeling triple-negative breast cancer heterogeneity: Effects of stromal macrophages, fibroblasts and tumor vasculature. J Theor Biol (2018) 452:56-68. doi: 10.1016/j.jtbi.2018.05.003

121. Yang D, Feng L, Dougherty CA, Luker KE, Chen D, Cauble MA, et al. In vivo targeting of metastatic breast cancer via tumor vasculature-specific nanographene oxide. Biomaterials (2016) 104:361-71. doi: 10.1016/ j.biomaterials.2016.07.029

122. Kozłowski J, Kozłowska A, Kocki J. Breast cancer metastasis - insight into selected molecular mechanisms of the phenomenon. Postepy Hig Med Dosw (2015) 69:447-51. doi: 10.5604/17322693.1148710

123. Leek RD, Lewis CE, Whitehouse R, Greenall M, Clarke J, Harris AL. Association of macrophage infiltration with angiogenesis and prognosis in invasive breast carcinoma. Cancer Res (1996) 56(20):4625-9.

124. Kolb R, Phan L, Borcherding N, Liu Y, Yuan F, Janowski AM, et al. Obesityassociated NLRC4 inflammasome activation drives breast cancer progression. Nat Commun (2016) 7:13007. doi: 10.1038/ncomms13007

125. Kolb R, Kluz P, Tan ZW, Borcherding N, Bormann N, Vishwakarma A, et al. Obesity-associated inflammation promotes angiogenesis and breast cancer via angiopoietin-like 4. Oncogene (2019) 38(13):2351-63. doi: 10.1038/ s41388-018-0592-6

126. Folkman J. Role of angiogenesis in tumor growth and metastasis. Semin Oncol (2002) 29(6 Suppl 16):15-8. doi: 10.1053/sonc.2002.37263

127. Esteves M, Monteiro MP, Duarte JA. Role of Regular Physical Exercise in Tumor Vasculature: Favorable Modulator of Tumor Milieu. Int J Sports Med (2020). doi: 10.1055/a-1308-3476

128. Wen ZH, Su YC, Lai PL, Zhang Y, Xu YF, Zhao A, et al. Critical role of arachidonic acid-activated mTOR signaling in breast carcinogenesis and angiogenesis. Oncogene (2013) 32(2):160-70. doi: 10.1038/onc.2012.47

129. Merendino N, Costantini L, Manzi L, Molinari R, D'Eliseo D, Velotti F. Dietary $\omega-3$ polyunsaturated fatty acid DHA: a potential adjuvant in the treatment of cancer. BioMed Res Int (2013) 2013:310186. doi: 10.1155/2013/ 310186

130. Darwito D, Dharmana E, Riwanto I, Budijitno S, Suwardjo S, Purnomo J, et al. Effects of Omega-3 Supplementation on Ki-67 and VEGF Expression Levels and Clinical Outcomes of Locally Advanced Breast Cancer Patients Treated with Neoadjuvant CAF Chemotherapy: A Randomized Controlled Trial Report. Asian Pac J Cancer Prev APJCP (2019) 20(3):911-6. doi: 10.31557/apjcp.2019.20.3.911 
131. Aiyengar TM, Chiranjeevi P, Rani HS. Role of Endothelial Nitric Oxide Synthase in Breast Cancer. In: SS Saravi, editor. Nitric Oxide Synthase Simple Enzyme-Complex Roles: InTech (2017).

132. Keshet R, Erez A. Arginine and the metabolic regulation of nitric oxide synthesis in cancer. Dis Models Mech (2018) 11(8):dmm033332. doi: $10.1242 / \mathrm{dmm} .033332$

133. Kornfeld S, Goupille C, Vibet S, Chevalier S, Pinet A, Lebeau J, et al. Reducing endothelial NOS activation and interstitial fluid pressure with $n-3$ PUFA offset tumor chemoresistance. Carcinogenesis (2011) 33(2):260-7. doi: $10.1093 /$ carcin/bgr274

134. Sabol RA, Bowles AC, Côté A, Wise R, O’Donnell B, Matossian MD, et al. Leptin produced by obesity-altered adipose stem cells promotes metastasis but not tumorigenesis of triple-negative breast cancer in orthotopic xenograft and patient-derived xenograft models. Breast Cancer Res (2019) 21(1):1-14. doi: 10.1186/s13058-019-1153-9

135. Barone I, Giordano C, Bonofiglio D, Andò S, Catalano S. The weight of obesity in breast cancer progression and metastasis: Clinical and molecular perspectives. Semin Cancer Biol (2020) 60:274-84. doi: 10.1016/ j.semcancer.2019.09.001

136. Haakinson DJ, Leeds SG, Dueck AC, Gray RJ, Wasif N, Stucky C-CH, et al. The Impact of Obesity on Breast Cancer: A Retrospective Review. Breast Oncol (2012) 19: (9):3012-8. doi: 10.1245/s10434-012-2320-8

137. Osman MA, Hennessy BT. Obesity Correlation with Metastases Development and Response to First-Line Metastatic Chemotherapy in Breast Cancer. Clin Med Insights: Oncol (2015) 9:CMO.S32812. doi: $10.4137 / \mathrm{cmo} . \mathrm{s} 32812$

138. Bousquenaud M, Fico F, Solinas G, Rüegg C, Santamaria-Martínez A. Obesity promotes the expansion of metastasis-initiating cells in breast cancer. Breast Cancer Res (2018) 20(104). doi: 10.1186/s13058-018-1029-4

139. Zuk PA, Zhu M, Ashjian P, De Ugarte DA, Huang JI, Mizuno H, et al. Human Adipose Tissue Is a Source of Multipotent Stem Cells. Mol Biol Cell (2002) 13(12):4279-95. doi: 10.1091/mbc.e02-02-0105

140. Janssen LME, Ramsay EE, Logsdon CD, Overwijk WW. The immune system in cancer metastasis: friend or foe? J ImmunoTher Cancer (2017) 5(1):1-14. doi: 10.1186/s40425-017-0283-9

141. Coffelt SB, Wellenstein MD, De Visser KE. Neutrophils in cancer: neutral no more. Nat Rev Cancer (2016) 16(7):431-46. doi: 10.1038/nrc.2016.52

142. Quail DF, Olson OC, Bhardwaj P, Walsh LA, Akkari L, Quick ML, et al. Obesity alters the lung myeloid cell landscape to enhance breast cancer metastasis through IL5 and GM-CSF. Nat Cell Biol (2017) 19(8):974-87. doi: $10.1038 /$ ncb3578

143. Cozzo AJ, Fuller, Ashley M, Makowski L. Contribution of Adipose Tissue to Development of Cancer. Compr Physiol (2018) 8(1):237-82. doi: 10.1002/ cphy.c170008

144. Donohoe CL, Lysaght J, O’Sullivan J, Reynolds JV. Emerging Concepts Linking Obesity with the Hallmarks of Cancer. Trends Endocrinol Metabol (2016) 28(1):46-62. doi: 10.1016/j.tem.2016.08.004

145. Joint WHOFAOUNUEC. Protein and amino acid requirements in human nutrition. World Health Organ Tech Rep Ser (2007) (935):1-265.

146. Rand WM, Pellett PL, Young VR. Meta-analysis of nitrogen balance studies for estimating protein requirements in healthy adults. Am J Clin Nutr (2003) 77(1):109-27. doi: 10.1093/ajcn/77.1.109

147. Medicine. Io. Dietary Reference Intakes: The Essential Guide to Nutrient Requirements. Washington, DC: The National Academies Press (2006).

148. Medicine. Io. Dietary Reference Intakes for Calcium, Phosphorus, Magnesium, Vitamin D, and Fluoride. Dietary Reference Intakes for Calcium, Phosphorus, Magnesium, Vitamin D, and Fluoride. The National Academies Collection: Reports funded by National Institutes of Health. Washington (DC: The National Academies Press (1997) p. 1-449.

149. Medicine. Io. Dietary Reference Intakes for Vitamin C, Vitamin E, Selenium, and Carotenoids. Dietary Reference Intakes for Vitamin C, Vitamin E, Selenium, and Carotenoids. Washington (DC: The National Academies Press (2000) p. 1-530.

150. Medicine. Io. Dietary Reference Intakes for Energy, Carbohydrate, Fiber, Fat, Fatty Acids, Cholesterol, Protein, and Amino Acids. Washington, DC: The National Academies Press (2005).

151. Medicine. Io. Dietary Reference Intakes Research Synthesis: Workshop Summary. Washington, DC: The National Academies Press (2006).
152. National Academies of Sciences E, and Medicine. Dietary Reference Intakes for Sodium and Potassium. In: M Oria, M Harrison and VA Stallings, editors. Dietary Reference Intakes for Sodium and Potassium. The National Academies Collection: Reports funded by National Institutes of Health. Washington (DC: The National Academies Press (2019). p. 1-595.

153. National Academies of Sciences E. Medicine. Guiding Principles for Developing Dietary Reference Intakes Based on Chronic Disease. S Kumanyika and MP Oria, editors. Washington, DC: The National Academies Press (2017). p. 334.

154. U.S. Department of Health and Human Services and U.S. Department of Agriculture. 2015-2020 Dietary Guidelines for Americans. 8th Edition. Washington, D. C. (2015) p. 1-144.

155. National Academies of Sciences E, and Medicine. A Health Equity Approach to Obesity Efforts: Proceedings of a Workshop. In: EA Callahan, editor. A Health Equity Approach to Obesity Efforts: Proceedings of a Workshop. Washington (DC: The National Academies Press (2019). p. 1-123.

156. Speakman JR. Use of high-fat diets to study rodent obesity as a model of human obesity. Int J Obes (Lond) (2019) 43(8):1491-2. doi: 10.1038/s41366019-0363-7

157. Hu S, Wang L, Yang D, Li L, Togo J, Wu Y, et al. Dietary Fat, but Not Protein or Carbohydrate, Regulates Energy Intake and Causes Adiposity in Mice. Cell Metab (2018) 28(3):415-31 e4. doi: 10.1016/j.cmet.2018.06.010

158. Ning M, Jeong H. High-Fat Diet Feeding Alters Expression of Hepatic DrugMetabolizing Enzymes in Mice. Drug Metab Dispos (2017) 45(7):707-11. doi: 10.1124/dmd.117.075655

159. Núñez NP CC, Perkins SN, Berrigan D, Jaque SV, Ingles SA, Bernstein L, et al. Extreme obesity reduces bone mineral density: complementary evidence from mice and women. Obes (Silver Spring) (2007) 15(8):1980-7. doi: 10.1038 /oby.2007.236

160. Sadler NC, Webb-Robertson BM, Clauss TR, Pounds JG, Corley R, Wright AT. High-Fat Diets Alter the Modulatory Effects of Xenobiotics on Cytochrome P450 Activities. Chem Res Toxicol (2018) 31(5):308-18. doi: 10.1021/acs.chemrestox.8b00008

161. Clemmensen C, Smajilovic S, Madsen AN, Klein AB, Holst B, BraunerOsborne H. Increased susceptibility to diet-induced obesity in GPRC6A receptor knockout mice. J Endocrinol (2013) 217(2):151-60. doi: 10.1530/ JOE-12-0550

162. De Angel RE, Blando JM, Hogan MG, Sandoval MA, Lansakara PD, Dunlap $\mathrm{SM}$, et al. Stearoyl gemcitabine nanoparticles overcome obesity-induced cancer cell resistance to gemcitabine in a mouse postmenopausal breast cancer model. Cancer Biol Ther (2013) 14(4):357-64. doi: 10.4161/cbt.23623

163. Ford NA, Rossi EL, Barnett K, Yang P, Bowers LW, Hidaka BH, et al. Omega-3-Acid Ethyl Esters Block the Protumorigenic Effects of Obesity in Mouse Models of Postmenopausal Basal-like and Claudin-Low Breast Cancer. Cancer Prev Res (Phila) (2015) 8(9):796-806. doi: 10.1158/19406207.CAPR-15-0018

164. Calle EE, Rodriguez C, Walker-Thurmond K, Thun MJ. Overweight, obesity, and mortality from cancer in a prospectively studied cohort of U.S. adults. $N$ Engl J Med (2003) 348(17):1625-38. doi: 10.1056/NEJMoa021423

165. Chen S, Chen CM, Zhou Y, Zhou RJ, Yu KD, Shao ZM. Obesity or overweight is associated with worse pathological response to neoadjuvant chemotherapy among Chinese women with breast cancer. PloS One (2012) 7 (7):e41380. doi: 10.1371/journal.pone.0041380

166. Shi Z, Rundle A, Genkinger JM, Cheung YK, Ergas IJ, Roh JM, et al. Distinct trajectories of fruits and vegetables, dietary fat, and alcohol intake following a breast cancer diagnosis: the Pathways Study. Breast Cancer Res Treat (2020) 179(1):229-40. doi: 10.1007/s10549-019-05457-9

167. Dawood S, Lei X, Litton JK, Buchholz TA, Hortobagyi GN, Gonzalez-Angulo AM. Impact of body mass index on survival outcome among women with early stage triple-negative breast cancer. Clin Breast Cancer (2012) 12 (5):364-72. doi: 10.1016/j.clbc.2012.07.013

168. Dydjow-Bendek D, Zagozdzon P. Total Dietary Fats, Fatty Acids, and Omega-3/Omega-6 Ratio as Risk Factors of Breast Cancer in the Polish Population - a Case-Control Study. In Vivo (2020) 34(1):423-31. doi: 10.21873/invivo.11791

169. Go Y, Chung M, Park Y. Dietary Patterns for Women With Triple-negative Breast Cancer and Dense Breasts. Nutr Cancer (2016) 68(8):1281-8. doi: 10.1080/01635581.2016.1225102 
170. Prieto-Hontoria PL, Perez-Matute P, Fernandez-Galilea M, Bustos M, Martinez JA, Moreno-Aliaga MJ. Role of obesity-associated dysfunctional adipose tissue in cancer: a molecular nutrition approach. Biochim Biophys Acta (2011) 1807(6):664-78. doi: 10.1016/j.bbabio.2010.11.004

171. Christ A, Lauterbach M, Latz E. Western Diet and the Immune System: An Inflammatory Connection. Immunity (2019) 51(5):794-811. doi: 10.1016/ j.immuni.2019.09.020

172. Hariharan D, Vellanki K, Kramer H. The Western Diet and Chronic Kidney Disease. Curr Hypertens Rep (2015) 17(3):16. doi: 10.1007/s11906-014-0529-6

173. Hintze KJ, Benninghoff AD, Cho CE, Ward RE. Modeling the Western Diet for Preclinical Investigations. Adv Nutr (Bethesda Md) (2018) 9(3):263-71. doi: 10.1093/advances/nmy002

174. Shively CA, Register TC, Appt SE, Clarkson TB, Uberseder B, Clear KYJ, et al. Consumption of Mediterranean versus Western Diet Leads to Distinct Mammary Gland Microbiome Populations. Cell Rep (2018) 25(1):47-56.e3. doi: 10.1016/j.celrep.2018.08.078

175. Varlamov O. Western-style diet, sex steroids and metabolism. Biochim Biophys Acta Mol Basis Dis (2017) 1863(5):1147-55. doi: 10.1016/ j.bbadis.2016.05.025

176. Zinöcker MK, Lindseth IA. The Western Diet-Microbiome-Host Interaction and Its Role in Metabolic Disease. Nutrients (2018) 10(3). doi: 10.3390/ nu10030365

177. Ho VW, Leung K, Hsu A, Luk B, Lai J, Shen SY, et al. A low carbohydrate, high protein diet slows tumor growth and prevents cancer initiation. Cancer Res (2011) 71(13):4484-93. doi: 10.1158/0008-5472.CAN-10-3973

178. Kiilerich P, Myrmel LS, Fjaere E, Hao Q, Hugenholtz F, Sonne SB, et al. Effect of a long-term high-protein diet on survival, obesity development, and gut microbiota in mice. Am J Physiol Endocrinol Metab (2016) 310(11):E886-99. doi: 10.1152/ajpendo.00363.2015

179. Moulton CJVR, Layman DK, Devkota S, Singletary KW, Wallig MA, Donovan SM. A high protein moderate carbohydrate diet fed at discrete meals reduces early progression of $\mathrm{N}$-methyl-N-nitrosourea-induced breast tumorigenesis in rats. Nutr Metab (Lond) (2010) 7(1):1-7. doi: 10.1186/ 1743-7075-7-1

180. Park YM, Steck SE, Fung TT, Merchant AT, Elizabeth Hodgson M, Keller JA, et al. Higher diet-dependent acid load is associated with risk of breast cancer:
Findings from the sister study. Int J Cancer (2019) 144(8):1834-43. doi: $10.1002 /$ ijc.31889

181. Levine ME, Suarez JA, Brandhorst S, Balasubramanian P, Cheng CW, Madia $\mathrm{F}$, et al. Low protein intake is associated with a major reduction in IGF-1, cancer, and overall mortality in the 65 and younger but not older population. Cell Metab (2014) 19(3):407-17. doi: 10.1016/j.cmet.2014.02.006

182. Mittendorfer B, Klein S, Fontana L. A word of caution against excessive protein intake. Nat Rev Endocrinol (2020) 16(1):59-66. doi: 10.1038/s41574019-0274-7

183. Castelló A, Pollán M, Buijsse B, Ruiz A, Casas AM, Baena-Cañada JM, et al. Spanish Mediterranean diet and other dietary patterns and breast cancer risk: case-control EpiGEICAM study. Br J Cancer (2014) 111(7):1454-62. doi: 10.1038/bjc.2014.434

184. Limon-Miro AT, Lopez-Teros V, Astiazaran-Garcia H. Dietary Guidelines for Breast Cancer Patients: A Critical Review. Adv Nutr (Bethesda $M d$ ) (2017) 8(4):613-23. doi: 10.3945/an.116.014423

185. De Cicco P, Catani MV, Gasperi V, Sibilano M, Quaglietta M, Savini I. Nutrition and Breast Cancer: A Literature Review on Prevention, Treatment and Recurrence. Nutrients (2019) 11(7):1-28. doi: 10.3390/nu11071514

186. Naghshi S, Sadeghi O, Willett WC, Esmaillzadeh A. Dietary intake of total, animal, and plant proteins and risk of all cause, cardiovascular, and cancer mortality: systematic review and dose-response meta-analysis of prospective cohort studies. BMJ (2020) 370(m2412):1-17. doi: 10.1136/ bmj.m 2412

Conflict of Interest: The authors declare that the research was conducted in the absence of any commercial or financial relationships that could be construed as a potential conflict of interest.

Copyright (c) 2021 Bustamante-Marin, Merlino, Devericks, Carson, Hursting and Stewart. This is an open-access article distributed under the terms of the Creative Commons Attribution License (CC BY). The use, distribution or reproduction in other forums is permitted, provided the original author(s) and the copyright owner(s) are credited and that the original publication in this journal is cited, in accordance with accepted academic practice. No use, distribution or reproduction is permitted which does not comply with these terms. 